\title{
The perception of taxi drivers in southern part of Saint Lucia, West Indies towards HIV/AIDS and condom use
}

\author{
Rotimi Orisatoki ${ }^{1 *}$, Oluwafemi Oguntibeju ${ }^{2}$ \\ From $16^{\text {th }}$ International Symposium on HIV and Emerging Infectious Diseases \\ Marseille, France. 24-26 March 2010
}

\section{Background}

The prevention and control of HIV/AIDS remains a challenge to health care providers in the Caribbean. Despite the threat posed by the rapid spread of the virus, many subgroups of the populations continue to engage in risky sexual behaviours. The taxi drivers belong to an occupation whose lifestyles while on duty have made them to be identified as highly susceptible. This study was conducted with the aim of understanding HIV-related knowledge and sexual behaviour with respect to condom use. The prevention and control of HIV/AIDS remains a challenge to health care providers in the Caribbean. Despite the threat posed by the rapid spread of the virus, many subgroups of the populations continue to engage in risky sexual behaviours. The taxi drivers belong to an occupation whose lifestyles while on duty have made them to be identified as highly susceptible. This study was conducted with the aim of understanding HIV-related knowledge and sexual behaviour with respect to condom use.

\section{Methods}

This study was conducted in May 2009 among male taxi drivers in the Hewanorra International Airport, St Lucia. This was a descriptive study using a semi-structured close-ended questionnaire. The data were collated and analysed using the Statistical Package for Social sciences 13.0 (SPSS 13.0) data base. Statistical significance was set at $\mathrm{p}<0.01$.

\section{Results}

Eighty questionnaires were distributed, sixty were correctly filled, showing a response rate of $75 \%$. The knowledge of HIV/AIDS was high among the drivers (78.3\%). More than $50 \%$ of the respondents do not use condom consistently for sexual intercourse.

\section{Discussion}

Some misconceptions about the mode of transmission of HIV/AIDS were observed. Also constraints to the affordability and availability were identified. Behaviour modification programmes should be taught periodically to this subgroup. The government should endeavour to make condoms more accessible especially in public places.

\section{Author details}

${ }^{1}$ Spartan Health Sciences University, School of Medicine, Vieux Fort, Saint Lucia. ${ }^{2}$ Cape Peninsula University of Technology, Bellville 7535, South Africa.

Published: 11 May 2010

doi:10.1186/1742-4690-7-S1-P144

Cite this article as: Orisatoki and Oguntibeju: The perception of taxi drivers in southern part of Saint Lucia, West Indies towards HIV/AIDS and condom use. Retrovirology 2010 7(Suppl 1):P144.

\footnotetext{
* Correspondence: rotioris@yahoo.com

${ }^{1}$ Spartan Health Sciences University, School of Medicine, Vieux Fort, Saint Lucia
} 